\title{
Evaluation of cytogenotoxicity, antioxidant and hypoglycemiant activities of isolate compounds from Mansoa hirsuta D.C. (Bignoniaceae)
}

\author{
JOQUEBEDE R. PEREIRA ${ }^{1}$, RAPHAEL F. QUEIROZ ${ }^{2}$, ERLÂNIA A. DE SIQUEIRA ${ }^{3}$, ANA CHRISTINA \\ BRASILEIRO-VIDAL ${ }^{3}$, ANTÔNIO E.G. SANT'ANA ${ }^{4}$, DANIEL M. SILVA ${ }^{1}$ and PAULO R.A. DE MELLO AFFONSO ${ }^{5}$ \\ ${ }^{1}$ Departamento de Química e Exatas, Universidade Estadual do Sudoeste da Bahia, \\ Av. José Moreira Sobrinho, s/n, 45208-091 Jequié, BA, Brazil \\ ${ }^{2}$ Departamento de Ciências Naturais, Universidade Estadual do Sudoeste da Bahia, Estrada \\ do Bem Querer, Km 4, 45031-900 Vitória da Conquista, BA, Brazil \\ ${ }^{3}$ Departamento de Genética, Universidade Federal de Pernambuco, Av. Professor \\ Moraes Rego, s/n, Cidade Universitária, 50732-970 Recife, PE, Brazil \\ ${ }^{4}$ Instituto de Química e Biotecnologia, Universidade Federal de Alagoas, Campus A.C. Simões, \\ Av. Lourival de Melo Mota, s/n, Tabuleiro do Martins, 57072-970 Maceió, AL, Brazil \\ ${ }^{5}$ Departamento de Ciências Biológicas, Universidade Estadual do Sudoeste da Bahia, \\ Av. José Moreira Sobrinho, s/n, 45208-091 Jequié, BA, Brazil
}

Manuscript received on September 5, 2016; accepted for publication on January 3, 2017

\begin{abstract}
Mansoa hirsuta (Bignoniaceae) is a native plant from caatinga in Brazilian semiarid. This plant has been locally used as antimicrobial and hypoglycemiant agents, but their action mechanisms and toxicity remain largely unknown. Therefore, we evaluated the composition and antioxidant, cytoprotective and hypoglycemiant effects of raw extract, fractions and compounds from leaves of M. hirsuta. The cytogenotoxic effects of ursolic and oleanolic acids, the main phytotherapic components of this plant, were assessed. The raw extract and fractions presented steroids, saponins, flavonols, flavanonols, flavanones, xanthones, phenols, tannins, anthocyanins, anthocyanidins and flavonoids. The ethyl acetate fraction inhibited efficiently the cascade of lipid peroxidation while the hydroalcoholic fraction was richer in total phenols and more efficient in capturing 2,2-diphenyl-1-picrylhydrazyl ('DPPH) and 2,2'-azinobis (3-ethylbenzthiazoline-6-sulfonic acid) $\left(\mathrm{ABTS}^{\circ+}\right)$ radicals. The isolated fraction of M. hirsuta also inhibited the $\alpha$-amylase activity. Cytotoxic effects were absent in both raw extract and fractions while ursolic+oleanolic acids were efficient in protecting cells after exposure to hydrogen peroxide. Moreover, this mixture of acid shad no significant interference on the mitotic index and frequency of nuclear and/ or chromosomal abnormalities in Allium cepa test. Therefore, M. hirsuta represents a potential source of phytochemicals against inflammatory and oxidative pathologies, including diabetes.
\end{abstract}

Key words: antioxidant, caatinga, cytotoxicity, hypoglycemiant, phytochemistry.

\section{INTRODUCTION}

Plants have been widely used in traditional medicine to prevent and treat several human pathologies,

Correspondence to: Paulo Roberto Antunes de Mello Affonso E-mail: paulomelloaffonso@yahoo.com.br besides playing a major role in the development of commercial pharmacological compounds such as aspirin, morphine, digoxin, vinblastine and vincristine (Yarnell 2000). In fact, about 4 to $5 \%$ of nearly 400,000 known species of higher plants should present some relevant biological activity, 
even though refined chemical and pharmacological analyses are scarce for most species (Heywood 2011).

Brazil is recognized as the country with the highest genetic diversity of plants worldwide, comprising about 15 to $20 \%$ of vegetal biodiversity (Elisabetsky and Costa-Campos 1996, Guerra and Nodari 2006). Besides the Amazon forest, other Brazilian regions are rich in both fauna and flora representing biodiversity hotspots, like the Atlantic Forest and Cerrado (Brazilian Savannah). Another unique biome in South America is the Caatinga (dry bushlands) distributed exclusively through semiarid region in northeastern and a small part of southeastern Brazil. Caatinga is characterized by a high number of endemic species of therapeutic value for local populations (Nogueira et al. 2010, Pereira Júnior et al. 2014).

Since most people living in semiarid Brazilian regions are economically and socially vulnerable, the utilization of Caatinga plants usually represents the only treatment option to local communities (De Toledo et al. 2011). As a matter of fact, several therapeutic drugs have been developed from native Brazilian species, like pilocarpine extracted from leaves of Pilocarpus jaborandi, emetine from Psychotria ipecacuanha or Cephaelis ipecacuanha and d-tubocurarine isolated from Chondrodendron tomentosum (Nogueira et al. 2010) among others.

Mansoa hirsuta D.C.(Figure 1a) known as cipóde-alho (Brazil) is a Bignoniaceae plant endemic of semiarid Brazilian region (Lemos and Zappi 2012) that stands out by their popularity and potential to the production of phytotherapic drugs and/or functional foods (D.M. Silva, unpublished data). In traditional medicine, the leaves of this species have been used to control diabetes (Chaves and Reinhard 2003, Agra et al. 2008) while the ethanol extract has inhibited the growth of Aspergillus niger and Fusarium oxysporum cultures (Rocha et a

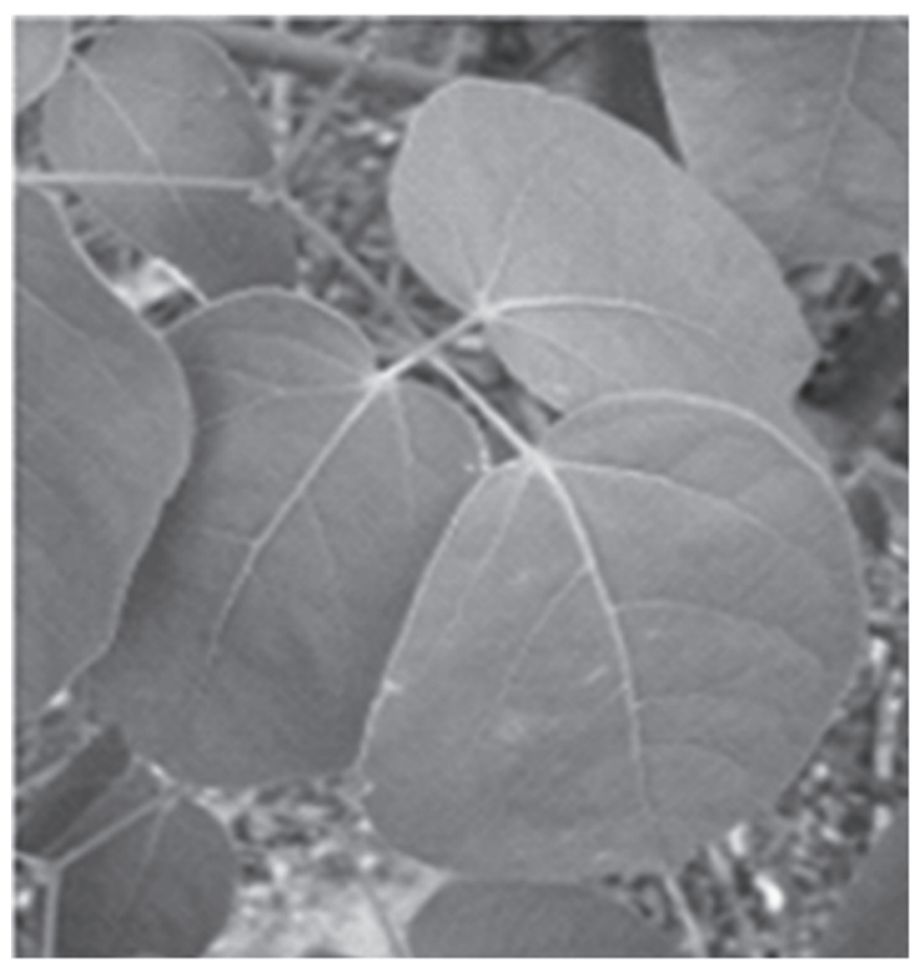

b

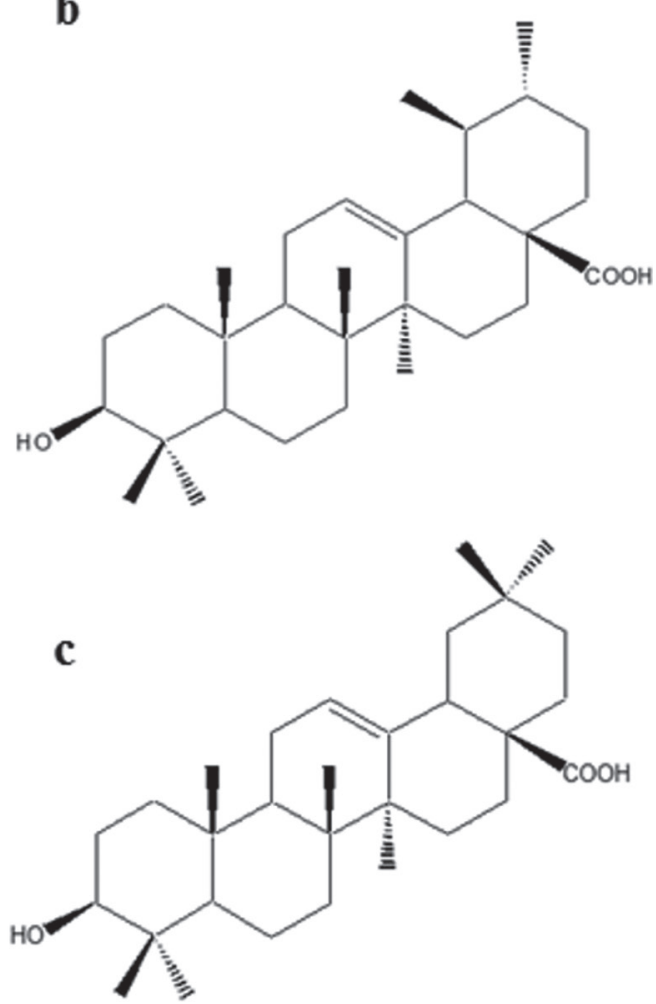

Figure 1 - (a) M. hirsuta D.C. collected in the municipality of Morro do Chapéu, Bahia, northeastern Brazil. (b) Chemical structure of ursolic acid. (c) Chemical structure of oleanolic acid. 
al. 2004). The antioxidant activity of M. hirsuta was also demonstrated by Braga et al. (2000) while isolated proanthocyanidins were capable of inhibiting angiotensin-converting enzyme (ACE) (Campana et al. 2009).

In a previous study, D.M. Silva (unpublished data) isolated a mixture (1:1) of ursolic (Figure 1b) and oleanolic (Figure 1c) acids from the ethyl acetate fraction of leaves of $M$. hirsuta, whose patent has been recorded in the National Institute of Industrial Propriety (INPI) under the number BR102015008180 (Silva et al. 2015). Both acids were efficient in reducing the proliferation of lymphocytes (>99\%) besides reducing the formation of nitric oxide by macrophages (in 41.5 to $44.1 \%$ ) (D.M. Silva, unpublished data).

Because of the biological potential and cultural of M. hirsuta, as well as the lack of detailed pharmacological studies about the utilization of this species in traditional medicine, the goal of the present work was to analyze antioxidant, cytoprotective and hypoglycemiant properties of the raw extract, fractions and compounds isolated from leaves. Moreover, putative cytotoxic, genotoxic and mutagenic side effects of the mixture of ursolic and oleanolic acids from the important plant species from caatinga were investigated to test their safety as potential pharmaceutical drugs.

\section{MATERIALS AND METHODS}

\section{REAGENTS AND PLANT MATERIAL}

For the comparative analyses based on thin-layer chromatography (TLC), silica gel 60 PF254 (Merck) and pure ethanol (Quemis) were used. The other analytical reagents (Folin-Ciocalteu reagent - FCR, 'DPPH, ABTS, $\beta$-carotene, butylated hydroxytoluene - BHT, tween 40, gallic acid, trolox, and amylase) were obtained from SigmaAldrich.

Specimens of $M$. hirsuta were collected in two municipalities (Santo Inácio and Gameleira do
Assuruá) in the state of Bahia, northeastern Brazil (11 $19^{\circ}$ 'S, $\left.42^{\circ} 40^{\prime} \mathrm{W}\right)$. The exsiccates were deposited in the Herbarium at Universidade Estadual de Feira de Santana (number 59456).

\section{PREPARATION OF RAW EXTRACT}

The leaves were dried, ground, weighed $(15.0 \mathrm{~kg})$ and submitted to hydroalcoholic extraction (50:50) in a percolator at room temperature $\left(27\right.$ to $\left.30^{\circ} \mathrm{C}\right)$ for $96 \mathrm{~h}$. The destilation of the solvent under reduced pressure in a rotary evaporator provided $1800 \mathrm{~g}$ of concentrated and homogeneous ethanol extract with $12 \%$ of yield.

\section{PHYTOCHEMICAL PROSPECTION AND} FRACTIONING OF ETHANOL EXTRACT

The phytochemical prospection of the raw ethanol extract (REE) and hydroalcoholic (HAF), alcoholic $(\mathrm{AF})$, ethyl acetate (EAF), chloroform (CF) and hexane (HF) fractions were carried out according to D.M. Silva (unpublished data). A solution of $1 \mathrm{~mol} / \mathrm{L} \mathrm{FeCl}_{3}$ was used to identify phenols and tannins. Flavonols, flavanonols, flavanones, and xanthones were identified via reaction with granulate magnesium and concentrated $\mathrm{HCl}$. The analysis of steroids and triterpenoids was performed with chloroform, anhydrous $\mathrm{Na}_{2} \mathrm{SO}_{4}$ and concentrated $\mathrm{H}_{2} \mathrm{SO}_{4}$. The identification of saponins was based on the formation of persistent and abundant foam. The alkaloids were identified by thin-layer chromatography (TLC) and revealed with Dragendorff's reagent.

A total of $250 \mathrm{~g}$ of the ethanol extract was fractioned in reverse phase using activated charcoal. After rotoevaporation, five fractions were obtained: hydroalcoholic fraction (HAF) 1:1 (130 $\mathrm{g}$ ), alcoholic fraction (AF) (35 g), ethyl acetate fraction (EAF) (40 g), chloroform fraction (CF) (41 g), and hexane fraction (HF) (4 g).

The EAF was submitted to column chromatography in silica gel yielding $15 \mathrm{~g}$ of EAF, which was again fractioned by column 
chromatography in silica gel using hexane $\left(\mathrm{C}_{6} \mathrm{H}_{14}\right)$, ethyl acetate (AcOEt) and a mixture of both solvents. This process resulted in 100 fractions with a mean volume of $5 \mathrm{~mL}$ each. After comparative analysis in TLC and revelation with anisaldehyde, ceric sulfate and/or iodine vapor, these fractions were separated into seven groups.

The fractions $\{\mathrm{F}-(43-60)\}(2.05 \mathrm{~g})$ and $\{\mathrm{F}-$ (74-100)\} (1.04 g) were then purified using column chromatography in silica gel, which resulted in the obtaining of two solid amorphous compounds named MHFA1 (60 mg) and MHFA2 $(70 \mathrm{mg})$, respectively. The structural identification of MHFA1 and MHFA2 was carried out by $1 \mathrm{H}-13 \mathrm{C}$ (DEPT $90^{\circ}$ and $135^{\circ}$ ), HSQC, HMBC, COSY and NOESY nuclear magnetic resonance spectroscopy. The results were compared to literature reports for both compounds (Seebacher et al. 2003, Moghaddam et al. 2007, Martins et al. 2013).

\section{QUANTIFICATION OF TOTAL PHENOLS BY FOLIN-} CIOCALTEU METHOD

The determination of total phenols in samples was accomplished by Folin-Ciocalteu method with modifications (Singleton et al. 1992). The samples were diluted in ethanol to a final concentration of $1 \mathrm{mg} / \mathrm{mL}$. Using assay tubes, $125 \mu \mathrm{L}$ of each sample was mixed with $125 \mu \mathrm{L}$ of FC Rand 1 $\mathrm{mL}$ of distilled water. After $3 \mathrm{~min}, 125 \mu \mathrm{L}$ of a saturated solution of $\mathrm{Na}_{2} \mathrm{CO}_{3}$ were added and the samples were incubated at $37^{\circ} \mathrm{C}$. After $30 \mathrm{~min}$, the absorbance of samples was measured at 750 $\mathrm{nm}$. The amount of total phenols in samples was determined based on the standard curve of gallic acid $(0.5$ at $25 \mu \mathrm{g})$, being expressed in equivalent $\mu \mathrm{g}$ of gallic acid per milligram of sample ( $\mu \mathrm{g}$ EGA/ $\mathrm{mg}$ ). The calibration curve equation of gallic acid was $\mathrm{y}=0.366 \mathrm{x}+0.0721, \mathrm{R}^{2}=0.9932$.

\section{TEST OF CO-OXIDATION OF B-CAROTENE/ LINOLEIC ACID}

The $\beta$-carotene/linoleic acid system was prepared with $8 \mathrm{~mL}$ of $\beta$-carotene diluted in chloroform
$(0.1 \mathrm{mg} / \mathrm{mL}), 40 \mu \mathrm{L}$ of linoleic acid and $400 \mu \mathrm{L}$ of tween 40. After agitation, the chloroform was evaporated and $400 \mathrm{~mL}$ of oxygen-saturated water were added up to the absorbance of 0.7 in $470 \mathrm{~nm}$, as estimated using Shimadzu UV mini 1240 UV visible scanning spectrophotometer. The final suspension $(3.0 \mathrm{~mL})$ was mixed with $40 \mu \mathrm{L}$ of sample $(1 \mathrm{mg} / \mathrm{mL})$ following immediately by the determination of absorbance. After incubation at $45^{\circ} \mathrm{C}$, the absorbance was established again within 15-min intervals for $2 \mathrm{~h}$. BHT was used as to establish the standard absorbance (Rufino 2007). The antioxidant activity was expressed in percentage of oxidation inhibition in relation to $100 \%$ of oxidation in the negative (sample-free) control.

\section{TOTAL ANTIOXIDANT ACTIVITY BY}

ABTS $^{\bullet+}$ RADICAL SCAVENGING

The antioxidant capacity of raw extract and fractions of $M$. hirsuta was also evaluated by their ability in scavenging ${ }^{\circ} \mathrm{DPPH}$ free radical (Brand-Williams et al. 1995, Rufino 2007). The extraction and fractions were diluted to a final concentration of 50 , 100,200 , and $300 \mu \mathrm{g} / \mathrm{mL}$. Afterwards, $300 \mu \mathrm{L}$ of each dilution were incubated in $1700 \mu \mathrm{L}$ of ethanol solution of ${ }^{\circ} \mathrm{DPPH}(70 \mu \mathrm{M})$ for $20 \mathrm{~min}$ at $25^{\circ} \mathrm{C}$. The measurement of absorbance was performed at a wavelength of $517 \mathrm{~nm}$ using a Gehaka $340 \mathrm{G}$ UV spectrophotometer. Ethanol was used as negative control while gallic acid and trolox were selected as positive controls. The percentage of antioxidant activity was plotted on a graph against the concentration of extracts, after adjustment of data by the rectangular hyperbolic equation to obtain the $\mathrm{CE}_{50}$, i.e., the required concentration of sample to reduce the free radical in $50 \%$.

TOTAL ANTIOXIDANT ACTIVITY BY ABTS ${ }^{\bullet+}$ RADICAL SCAVENGING

The ability in scavenging the $\mathrm{ABTS}^{\circ}{ }^{+}$radical was performed as that described by Re et al. (1999) with modifications. Firstly, $87.5 \mu \mathrm{L}$ of ammonium 
persulfate $(140 \mathrm{mM})$ was incubated in $5 \mathrm{~mL}$ of ABTS $(7 \mathrm{mM})$ for $16 \mathrm{~h}$ at $25^{\circ} \mathrm{C}$, protected from light, to produce the $\mathrm{ABTS}^{\bullet+}$ radical. The final solution was diluted in ethanol up to absorbance of 0.70 \pm 0.02 at $734 \mathrm{~nm}$. The extract and fractions were diluted $(2,6,12,5,25,50$, and $100 \mu \mathrm{g} / \mathrm{mL})$, and $300 \mu \mathrm{L}$ of each dilution were incubated in ethanol solution of $\mathrm{ABTS}^{\circ+}(1700 \mu \mathrm{L})$ for $20 \mathrm{~min}$ at $25^{\circ} \mathrm{C}$. The absorbance values were determined at $734 \mathrm{~nm}$. Ethanol was used as negative control while gallic acid and trolox were used as positive controls. The rate of antioxidant activity was plotted on a graph against the extract concentration was described in the previous section.

\section{ASSAY OF CELL VIABILITY}

Hamster V79 fibroblasts were grown in Dulbecco's Modified Eagle Medium (DMEM) with $10 \%$ of fetal bovine serum, penicillin $(100 \mathrm{U} / \mathrm{mL})$ and streptomycin $(100 \mu \mathrm{g} / \mathrm{mL})$ at $37^{\circ} \mathrm{C}$ in a $5 \% \mathrm{CO}_{2}$ atmosphere. The medium was changed when the culture reached $80 \%$ of confluence, being spread to other culture bottles.

The cell viability was firstly determined by 3-(4,5-dimethylthiazol-2-yl)-2,5-diphenyltetrazolium bromide (MTT) method, which allows evaluating the mitochondrial activity in viable cells (Hansen et al. 1989). The cells (1x10/well) were dropped into 96-well plates and pre-incubated with the extraction and fractions of $M$. hirsuta at a concentration of 0 to $100 \mu \mathrm{g} / \mathrm{mL}$ at $37^{\circ} \mathrm{C}$ for $24 \mathrm{~h}$. The MTT was added $(0.25 \mathrm{mg} / \mathrm{mL})$ to the medium and cells were incubated at $37^{\circ} \mathrm{C}$. After $3 \mathrm{~h}$, the absorbance was measured in a microplate reader at 570 $\mathrm{nm}$ (reference wavelength $=630 \mathrm{~nm}$ ). The residual metabolic activity of cells was calculated as a percentage in relation to the negative control. As positive control, the cells were cultured with $1 \%$ Triton $\mathrm{X}-100$.

\section{CYTOPROTECTIVE ACTIVITY}

After culturing the fibroblasts as commented above, cell samples $\left(1 \times 10^{4} /\right.$ well $)$ were placed into a 96-well plate and pre-incubated at $37^{\circ} \mathrm{C}$ with the extract and fractions of M. hirsuta $(10 \mu \mathrm{g} /$ $\mathrm{mL}$ ). After $24 \mathrm{~h}$, the cells were washed twice in saline phosphate buffer (PBS). The medium was changed, and $\mathrm{H}_{2} \mathrm{O}_{2}(100 \mu \mathrm{M})$ was added, following incubation for $4 \mathrm{~h}$. The residual cell viability was determined as described in MTT method. Ethanol $(5 \%)$ and tempol $(10 \mu \mathrm{M})$ were used as negative and positive controls, respectively.

\section{ANTIOXIDANT ACTIVITY IN CELL MODEL}

To determine the antioxidant activity of isolated extract and fractions in cells, cultured fibroblasts (1x10 $/$ well) were plated, pre-incubated, incubated, washed, and re-incubated with $\mathrm{H}_{2} \mathrm{O}_{2}$ as described in the experiment of cytoprotective activity. Afterwards, the cells were washed in PBS, incubated in 2', 7'-dichlorofluorescein diacetate (DCFH-DA) at $10 \mu \mathrm{M}$ for $30 \mathrm{~min}$ at $37^{\circ} \mathrm{C}$ in a dark chamber. The extracellular DCFH-DA was removed after washing the cells twice in PBS. The oxidation of DCFH was monitored by fluorescence $\left(\lambda_{\mathrm{ex}}=485 \mathrm{~nm} ; \lambda_{\mathrm{ex}}=520 \mathrm{~nm}\right)$ in a microplate reader in as much as the fluorescent signal that indicates the intracellular redox state. Again, ethanol (5\%) and tempol $(10 \mu \mathrm{M})$ were selected as negative and positive controls, respectively.

\section{TEST OF $\alpha$-AMYLASE ACTIVITY}

The $\alpha$-amylase inhibitory activity of extract and fractions was determined according to Bernfeld (1955). For that, swine pancreatic $\alpha$-amylase (EC 3.2.1.1, type VI, Sigma) was diluted in $4 \mathrm{~mL}$ of phosphate buffer $(10 \mathrm{mM})$ up to a concentration of $180 \mu \mathrm{g} / \mathrm{mL}$. Afterwards, $100 \mu \mathrm{L}$ of enzyme solution was incubated with $5 \mu \mathrm{L}$ of sample $(200 \mu \mathrm{L} / \mathrm{mL})$ for $15 \mathrm{~min}$ at $37^{\circ} \mathrm{C}$. Then, the residual activity of amylase was determined using Bioclin commercial kit. Acarbose (EMS Sigma Pharma) was used as positive control while ethanol was used as negative control. 
TOXICOLOGY TESTS OF URSOLIC+OLEANOLIC ACIDS

The toxicity test was based on the Allium cepa system (Leme and Marin-Morales 2009) to verify the toxicity, cytotoxicity, genotoxicity, and mutagenicity at chromosome level of ursolic and oleanolic acids (UOA) fraction from M. hirsuta. In this test, three concentrations (100, 10 and $1 \mu \mathrm{g} /$ $\mathrm{mL}$ ) of a mixture of ursolic +oleanolic acids diluted in $0.1 \%$ dimethyl sulfoxide (DMSO) were used. Both distilled water and $0.1 \%$ DMSO (solvent) were used as negative controls while $4 \times 10^{-4} \mathrm{M}$ methyl methanesulfonate (MMS) and the herbicide trifluralin $\left(\mathrm{C}_{13} \mathrm{H}_{16} \mathrm{~F}_{3} \mathrm{~N}_{3} \mathrm{O}_{4}\right)$ at 0.84 ppm were used as positive controls.

Seeds of A. cepa (Vale Ouro - IPA 11), provided by the Instituto Agronômico de Pernambuco - IPA, were cultured in moist Petri plates with distilled water $\left(150\right.$ seeds/plate) at $25 \pm 5^{\circ} \mathrm{C}$. After reaching $1 \mathrm{~cm}$ in length, they were transferred to Petri plates containing the test solutions. After, $24 \mathrm{~h}$ the roots were measured for toxicity evaluation. The roots were fixed in Carnoy's fixative (ethanol: acetic acid; $3: 1$ ) and stored at $-20^{\circ} \mathrm{C}$ up to preparation of slides to evaluate cytotoxicity, genotoxicity and mutagenicity.

The stored roots were washed three times in distilled water (5 min each) and hydrolyzed in $1 \mathrm{~N} \mathrm{HCl}$ at $60^{\circ} \mathrm{C}$ for $10 \mathrm{~min}$. Afterwards, the roots were transferred to amber flasks containing Schiff Reactive (Merck) and stored for $2 \mathrm{~h}$ in dark chamber. Then, they were washed in distilled water, squashed over a glass slide containing a drop of acetic carmim (2\%) and the slides were mounted with Entellan (Merck). A total of 10 slides were analyzed per treatment (500 cells/slide, totaling 5,000 cells/treatment) under optic microscope.

The following parameters were evaluated: mean length of roots (toxicity), mitotic index (cytotoxicity), frequency of chromosomal abnormalities (genotoxicity) and index of chromosomal breakages and micronuclei (mutagenicity at chromosomal level). The results were compared to the negative and positive controls.

\section{STATISTICAL ANALYSIS}

All analyses were performed in triplicates and the results were expressed in mean \pm standard deviation values. The normality of data was verified by Shapiro-Wilk's test $(\mathrm{p}>0.05)$. The results from antioxidant tests were analyzed by Kruskal-Wallis test and post-hoc Dunn's test. The correlation was established according to Spearman's correlation coefficient. The results of $\alpha$-amylase inhibition were analyzed by Mann-Whitney's test. The level of significance for statistical analyses was $p<0.05$, using the software GraphPad Prism (6.0). For the A. cepa test, the differences among treatments and control were based on Kruskal-Wallis, followed by a posteriori Tukey's test $(\mathrm{p}<0.05)$, using the software Statistica (8.0).

\section{RESULTS}

The phytochemistry prospection of the raw ethanol extract (REE), hydroalcoholic (HAF), alcoholic (AF), ethyl acetate (EAF), chloroform (CF) and hexane (HF) fractions, and the isolated fraction containing a mixture of ursolic and oleanolic acids (UOA) from $M$. hirsuta are shown in Table I. The raw extract and fractions presented phenols, tannins, anthocyanins, anthocyanidins, and flavonoids. Steroids and triterpenoids were observed in both REE and EAF while saponins, flavonols, flavanonols, flavanones, and xanthones were identified in REE, HAF, and AF. The chloroform and hexane fractions contained only fatty acids and have not been analyzed in this study.

The MHFA1 and MHFA2 compounds were identified as ursolic and oleanolic acids by spectrophotometry (D.M. Silva, unpublished data) and comparisons to previous reports (Seebacher et al. 2003, Moghaddam et al. 2007, Martins et al. 2013). 
TABLE I

Qualitative phytochemical prospection of extract and fractions isolated from leaves of $M$. hirsuta.

\begin{tabular}{ccccccc}
\hline \multirow{2}{*}{ Chemical constituents } & \multicolumn{7}{c}{ Extract and fractions } \\
& REE & HAF & AF & EAF & HF & CF \\
\hline Phenols & + & + & + & + & - & - \\
Tannins & + & + & + & + & - & - \\
Steroids & + & - & - & + & + & + \\
Triterpenes & + & - & - & + & + & + \\
Saponins & + & + & + & - & - & - \\
Alkaloids & - & - & - & - & - & - \\
Flavonols & + & + & + & - & - & - \\
Flavanonols & + & + & + & - & - & - \\
Flavanones & + & + & + & - & - & - \\
Xanthones & + & + & + & - & - & - \\
Anthocyanins & + & + & + & + & - & - \\
Anthocyanidins & + & + & + & + & - & - \\
Flavonoids & + & + & + & + & - & - \\
\hline
\end{tabular}

$(+)=$ Presence of reaction; $(-)=$ Lack of reaction. REE: raw ethanol extract; HAF: hydroalcoholic fraction; AF: alcoholic fraction; EAF: ethyl acetate fraction; HF: hexane fraction; CF: chloroform fraction.

The quantification of total phenols in REE and fractions of $M$. hirsuta are shown in Table II. The raw extract from leaves presented $\sim 20 \mu \mathrm{g}$ EGA/mg. After fractioning, most of phenols were concentrated in the AF ( $\sim 56 \mu \mathrm{g} \mathrm{EGA} / \mathrm{mg})$.

The antioxidant potential of REE, HAF, AF, EAF and UOA fraction of $M$. hirsuta based on the co-oxidation of $\beta$-carotene/linoleic acid (Table II) revealed that EAF had the highest inhibition of oxidation (79.36\%), followed by HAF, REE,
$\mathrm{AF}$ and UOA $(45.3 \%, 43.2 \%, 39.2$, and $21.58 \%$, respectively).

On the other hand, the HAF was more efficient in scavenging ${ }^{\circ} \mathrm{DPPH}$ radical $\left(\mathrm{CE}_{50}=29.1 \mu \mathrm{g} / \mathrm{mL}\right)$ when compared to the other fractions, even though this value was lower than that presented by the standard trolox $\left(\mathrm{CE}_{50}=1.5 \mu \mathrm{g} / \mathrm{mL}\right)$ and gallic acid $\left(\mathrm{CE}_{50}=1.4 \mu \mathrm{g} / \mathrm{mL}\right)$ tests. Likewise, HAF presented the highest antioxidant activity $\left(\mathrm{CE}_{50}=5.2 \mu \mathrm{g} / \mathrm{mL}\right)$ in $\mathrm{ABTS}^{\circ+}$ test, followed by $\mathrm{AF}\left(\mathrm{CE}_{50}=6.8 \mu \mathrm{g} / \mathrm{mL}\right)$,

TABLE II

Antioxidant activity of raw ethanol extract and fractions of $M$. hirsuta.

\begin{tabular}{ccccc}
\hline Samples & Total phenols $\boldsymbol{\mu g}$ EGA/mg & $\begin{array}{c}\boldsymbol{\beta} \text {-carotene/linoleic acid } \\
\text { system (\% IO) }\end{array}$ & DPPH CE $_{\mathbf{5 0}}(\boldsymbol{\mu g} / \mathbf{m L})$ & $\mathbf{A B T S}^{\bullet+} \mathbf{C E}_{\mathbf{5 0}}(\boldsymbol{\mu g} / \mathbf{m L})$ \\
\hline REE & $20.3 \pm 0.8$ & $43.2 \pm 0.1^{\mathrm{a}}$ & $57.1 \pm 5.6^{\mathrm{b}, \mathrm{c}}$ & $14.9 \pm 1.4^{\mathrm{b}, \mathrm{c}}$ \\
HAF & $07.2 \pm 0.5$ & $39.3 \pm 0.1^{\mathrm{a}}$ & $29.1 \pm 1.1^{\mathrm{b}, \mathrm{c}}$ & $5.2 \pm 0.1$ \\
AF & $55.7 \pm 2.1$ & $45.2 \pm 0.1^{\mathrm{a}}$ & $45.9 \pm 1.8^{\mathrm{b}, \mathrm{c}}$ & $6.8 \pm 0.1$ \\
EAF & $06.8 \pm 0.2$ & $79.4 \pm 0.1$ & $59.0 \pm 9.9^{\mathrm{b}, \mathrm{c}}$ & $17.9 \pm 0.1^{\mathrm{b}, \mathrm{c}}$ \\
UOA & $00.2 \pm 0.1$ & $21.6 \pm 0.1^{\mathrm{a}}$ & $49.4 \pm 1.7^{\mathrm{b}, \mathrm{c}}$ & $34.9 \pm 3.8^{\mathrm{b}, \mathrm{c}}$ \\
BHT & - & $96.5 \pm 0.1$ & - & - \\
Trolox & - & - & $1.5 \pm 0.1$ & $1.2 \pm 0.1$ \\
Gallic acid & - & - & $1.4 \pm 0.1$ & $1.1 \pm 0.1$ \\
\hline
\end{tabular}

${ }^{\mathrm{a}} \mathrm{p}<0.05$, when compared to BHT, according to Kruskal-Wallis and post-hoc Dunn's test; ${ }^{\mathrm{b}} \mathrm{p}<0.05$ when compared to trolox according to Kruskal-Wallis and post-hoc Dunn's test; ${ }^{c} p<0.05$ when compared to gallic acid, according to Kruskal-Wallis and post-hoc Dunn's test; REE: raw ethanol extract; HAF: hydroalcoholic fraction; AF: alcoholic fraction; EAF: ethyl acetate fraction; UOA: ursolic and oleanolic acids. Results expressed in mean \pm standard deviation $(n=3)$. (-) Non-applicable. 
both comparable to the values obtained with trolox (Table II).

Moreover, the fibroblasts incubated with the extract and fractions of $M$. hirsuta remained viable even at the highest tested concentrations (100 $\mu \mathrm{g} / \mathrm{mL}$ ) (Figure 2). In addition, both extract and fractions $(10 \mu \mathrm{g} / \mathrm{mL})$ were also effective in protecting the cells against apoptosis caused by exposure to $\mathrm{H}_{2} \mathrm{O}_{2}$ (Figure 3). Thus, the compounds of $M$. hirsuta were characterized by cytoprotective activity, particularly remarkable for the UOA fraction $(76.8 \%)$. Accordingly, the reduction of oxidation by $\mathrm{H}_{2} \mathrm{O}_{2}$ in fibroblasts by the REE and fractions $(10 \mu \mathrm{g} / \mathrm{mL})$ was higher for the UOA fraction $(\sim 83 \%)$ (Figure 4$)$. For comparison, tempol $(10 \mu \mathrm{M})$, a well-recognized antioxidant (Soule et al. 2007), reduced $\mathrm{H}_{2} \mathrm{O}_{2}$-mediated death and ameliorated the oxidative stress in cells in around $53 \%$.

The evaluation of the ability in inhibiting the glycolytic activity of $\alpha$-amylase by the REE and fractions (at $200 \mu \mathrm{g} / \mathrm{mL}$ ) of $M$. hirsuta revealed that only the isolated UOA fraction was significantly efficient, with inhibition rates of $\sim 72 \%$ (Table III).

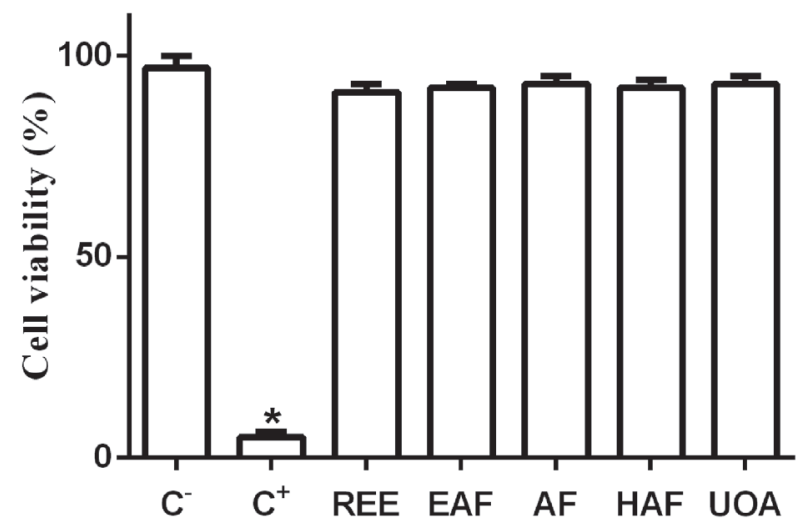

Figure 2 - Cell viability (\%) after incubation of fibroblasts with raw ethanol extract (REE), hydroalcoholic (HAF), alcoholic (AF), ethyl acetate (EAF) fractions and ursolic and oleanolic acids mixture (UOA) from $M$. hirsuta at $100 \mu \mathrm{g} / \mathrm{mL}$ for $24 \mathrm{~h}$ $\left(37^{\circ} \mathrm{C}\right)$ followed by incubation in MTT. Positive control $\left(\mathrm{C}^{+}\right)$: Triton X-100 (1\%). Negative control $\left(\mathrm{C}^{-}\right)$: cells from exposure to extract and fractions. ${ }^{*} \mathrm{p}>0.05$, when compared to the negative control.

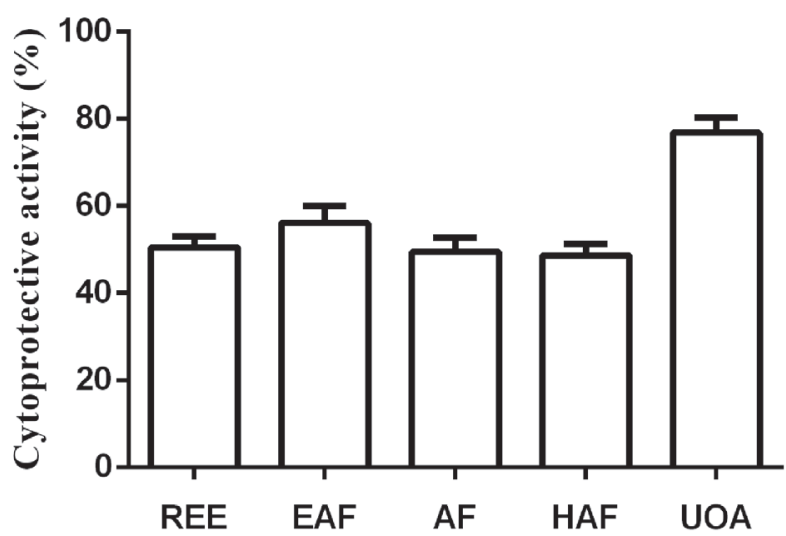

Figure 3 - Cytoprotective activity (\%) of the raw ethanol extract (REE), ethyl acetate (EAF), alcoholic (AF), and hydroalcoholic (HAF) fractions and ursolic and oleanolic acids mixture (UOA) at $10 \mu \mathrm{g} / \mathrm{mL}$ from $M$. hirsuta after exposure to $\mathrm{H}_{2} \mathrm{O}_{2}(100 \mu \mathrm{M})$. The residual viability was determined by assay with MTT.

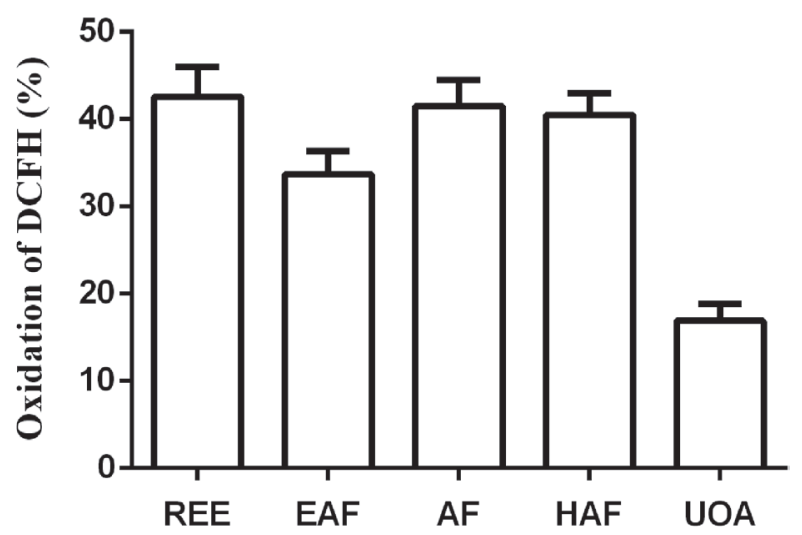

Figure 4 - Antioxidant activity in cell model of the raw ethanol extract (REE), hydroalcoholic (HAF), alcoholic (AF), ethyl acetate (EAF) fractions and ursolic and oleanolic acids mixture (UOA) at $10 \mu \mathrm{g} / \mathrm{mL}$ from $M$. hirsuta after exposure to $\mathrm{H}_{2} \mathrm{O}_{2}$ $(100 \mu \mathrm{M})$. The cells were incubated with DCFH-DA $(10 \mu \mathrm{M})$ for $30 \mathrm{~min}$, and the oxidation was monitored by fluorescence signals.

Therefore, a curve comparing concentration versus effect was built only for this fraction (Figure 5). We observed that the mixture of ursolic and oleanolic acids was effective with $\mathrm{IC}_{50}$ values of $29.6 \pm 0.2$, remarkably lower than those obtained for acarbose $\left(\mathrm{IC}_{50}=37.2 \pm 5.2\right)$, a well-known and clinically available enzyme inhibitor.

Considering the cytoprotective, hypoglycemiant and antioxidant activities of UOA fraction, the 
TABLE III

Inhibition of $\alpha$-amylase by the raw extract and fractions of $M$. hirsuta at $200 \mu \mathrm{g} / \mathrm{mL}$.

\begin{tabular}{cc}
\hline Extract and fractions & Inhibition rate $(\%)$ \\
\hline REE & - \\
HAF & - \\
AF & - \\
EAF & - \\
UOA & $71.8 \pm 5.7$ \\
\hline
\end{tabular}

REE: raw ethanol extract; HAF: hydroalcoholic fraction; AF: alcoholic fraction; EAF: ethyl acetate fraction; UOA: ursolic and oleanolic acids. (-) No inhibition.

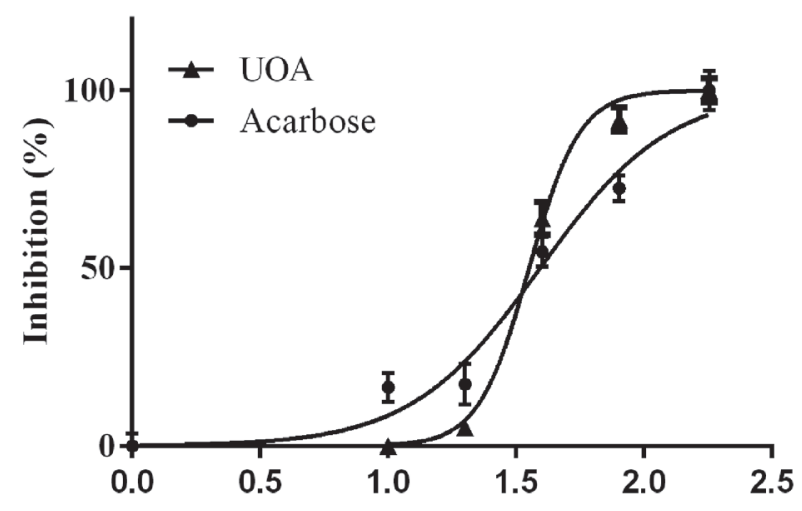

Figure 5 - Curve of concentration versus inhibition effects over $\alpha$-amylase by the isolated UOA (ursolic and oleanolic acids) fraction of $M$. hirsuta when compared to acarbose. The $\mathrm{IC}_{50}$ was determined by the hyperbolic adjustment of data in the software GraphPad $\left(\mathrm{C}^{+}\right.$: Acarbose; UOA: ursolic and oleanolic acids). toxicity tests were performed in A. cepa system only for the mixture of ursolic and oleanolic acids in order to verify their potential clinical use. Indeed, the values of the mean root length (MRLV) and mitotic index (MI) of meristem cells exposed to the tested concentrations of UOA fraction from $M$. hirsuta and $0.1 \%$ DMSO had no significant differences in relation to the negative control (Table IV).

After $24 \mathrm{~h}$ of exposure to the mixture of both acids, the meristem cells of $A$. cepa presented the following chromosomal alterations: nuclear buds (NB), micronuclei (MN), chromosomal breakage (CB), chromosomal losses (CL), chromosomal bridges $(\mathrm{CBr})$ and $\mathrm{C}$-metaphase $(\mathrm{C}-\mathrm{M})$ (Figure 6). However, the frequency of these abnormalities in the three tested concentrations of UOA and

TABLE IV

Value of mean root length (MRLV) and mitotic index (MI) in meristem cells of Allium cepa after exposure to distinct concentrations of ursolic and oleanolic acids (UOA) mixture of Mansoa hirsuta.

\begin{tabular}{cccc}
\hline \multicolumn{2}{c}{ Treatments } & MRLV (cm) & MI \\
\hline Negative control & Distilled water & $2.03 \pm 0.36$ & $6.06 \pm 0.55$ \\
& $0.1 \% \mathrm{DMSO}$ & $1.89 \pm 0.65$ & $6.36 \pm 0.75$ \\
UOA mixture & $0.001 \mathrm{mg} / \mathrm{mL}$ & $2.05 \pm 0.42$ & $6.50 \pm 0.64$ \\
& $0.01 \mathrm{mg} / \mathrm{mL}$ & $2.11 \pm 0.46$ & $6.38 \pm 0.65$ \\
& $0.1 \mathrm{mg} / \mathrm{mL}$ & $1.93 \pm 0.53$ & $5.42 \pm 0.59$ \\
Positive control & MMS & $2.10 \pm 0.31$ & $3.26 \pm 0.51^{*}$ \\
& TRI & $1.49 \pm 0.31^{*}$ & $4.07 \pm 0.61^{*}$ \\
\hline
\end{tabular}

MMS: methyl methanesulfonate; DMSO: dimethyl sulfoxide; TRI: Trifluralin. ${ }^{*} \mathrm{p}<0.05$ when compared to the negative control (Kruskal-Wallis test followed by post-hoc Tukey's test). 
$0.1 \%$ DMSO (solvent) was low and similar to the negative control (Table IV). Similarly, no significant increases in the genotoxicity index - IGen (total of chromosomal alterations) or mutagenicity - IMut $(\mathrm{MN}+\mathrm{CB})$ were detected when cells were exposed to the different concentrations of these compounds (Table V). On the other hand, as expected, the chromosomal aberrations in meristem cells from positive controls were significantly increased. The MMS induced the formation of MN and CB, characterizing a clastogenic activity, while trifluralin presented aneugenic effects once it increased the number of nuclear buds, chromosomal losses and bridges (Table V).

\section{DISCUSSION}

Even though $M$. hirsuta represents a typical plant species of Caatinga (Albuquerque et al. 2007, Nogueira et al. 2010) with regional use in folk medicine, chemical and biological studies in this species remain scarce(D.M. Silva, unpublished data, Zoghbi et al. 2009, Silva et al. 2015). Considering

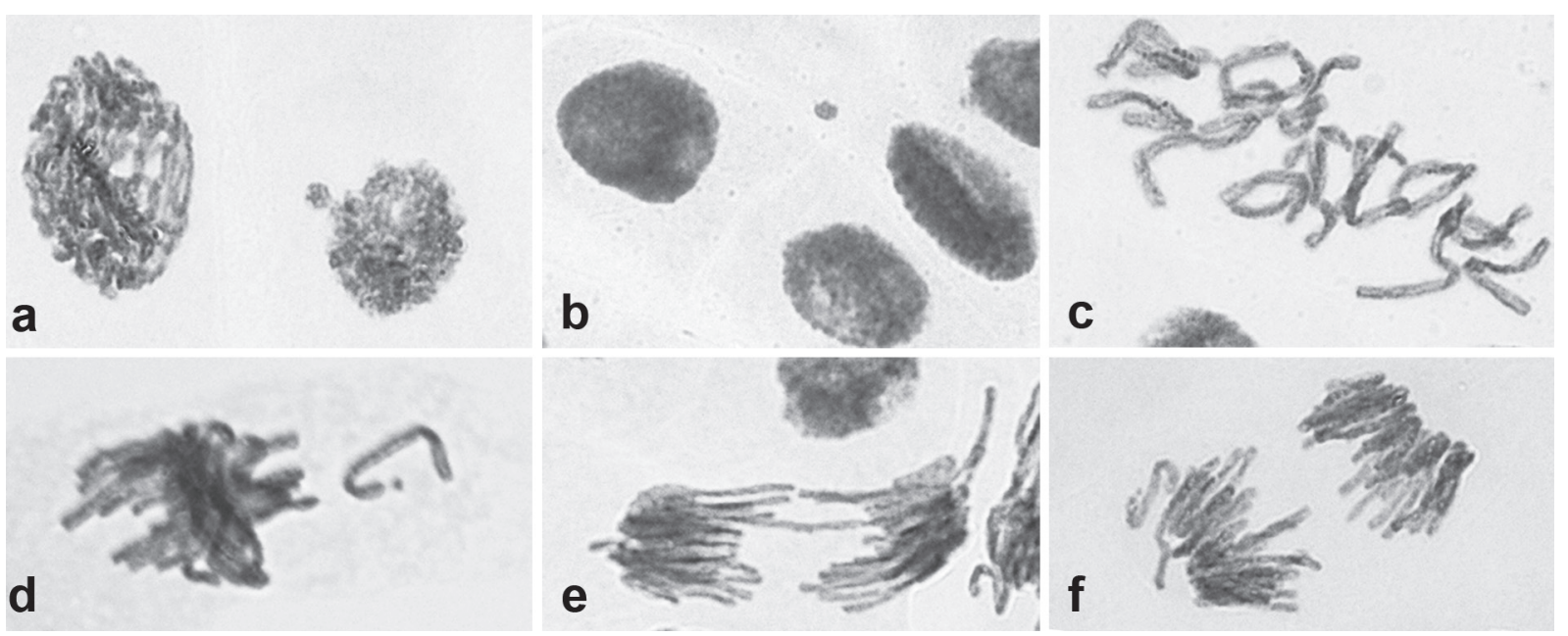

Figure 6 - Chromosomal abnormalities in meristem cells of Allium cepa exposed to the mixture of ursolic and oleanolic acids of Mansoa hirsuta: (a) nuclear bud $(100 \mu \mathrm{g} / \mathrm{mL})$; (b) micronucleus $(100 \mu \mathrm{g} / \mathrm{mL})$; (c) C-metaphase $(100 \mu \mathrm{g} / \mathrm{mL})$; (d) chromosomal loss $(10 \mu \mathrm{g} / \mathrm{mL})$; (e) chromosomal bridge $(1 \mu \mathrm{g} / \mathrm{mL})$; (f) anaphase with chromosomal loss $(10 \mu \mathrm{g} / \mathrm{mL})$.

TABLE V

Frequency of chromosomal and nuclear abnormalities in meristem cells after exposure to distinct concentrations of ursolic and oleanolic acids mixture from Mansoa hirsuta based on the Allium cepa test system.

\begin{tabular}{ccccccccc}
\hline & \multicolumn{7}{c}{ Chromosomal and nuclear abnormalities / 5.000 meristem cells } \\
\cline { 2 - 9 } & NB & CL & C-M & CBr & MN & CB & IMut & IGen \\
\hline NC & $\mathbf{0 . 0 8} \pm \mathbf{0 . 2 4}$ & $\mathbf{0 . 0 8} \pm \mathbf{0 . 1 0}$ & $\mathbf{0 . 0 6} \pm \mathbf{0 . 0 9}$ & $\mathbf{0 . 1 8} \pm \mathbf{0 . 2 1}$ & $\mathbf{0 . 1 3} \pm \mathbf{0 . 1 4}$ & $\mathbf{0 . 0 6} \pm \mathbf{0 . 0 9}$ & $\mathbf{0 . 1 9} \pm \mathbf{0 . 1 7}$ & $\mathbf{0 . 4 0} \pm \mathbf{0 . 3 7}$ \\
$\mathbf{0 . 1 \%}$ DMSO & $0.04 \pm 0.08$ & $0.08 \pm 0.13$ & $0.02 \pm 0.06$ & $0.24 \pm 0.15$ & $0.30 \pm 0.30$ & $0.04 \pm 0.08$ & $0.34 \pm 0.30$ & $0.38 \pm 0.20$ \\
$\mathbf{1}$ & $0.00 \pm 0.00$ & $0.06 \pm 0.13$ & $0.10 \pm 0.18$ & $0.30 \pm 0.16$ & $0.22 \pm 0.19$ & $0.22 \pm 0.21$ & $0.44 \pm 0.22$ & $0.46 \pm 0.27$ \\
$\mathbf{1 0}$ & $0.00 \pm 0.00$ & $0.04 \pm 0.12$ & $0.06 \pm 0.13$ & $0.22 \pm 0.17$ & $0.24 \pm 0.23$ & $0.20 \pm 0.20$ & $0.44 \pm 0.38$ & $0.32 \pm 0.22$ \\
$\mathbf{1 0 0}$ & $0.02 \pm 0.06$ & $0.08 \pm 0.10$ & $0.04 \pm 0.06$ & $0.20 \pm 0.18$ & $0.18 \pm 0.17$ & $0.16 \pm 0.22$ & $0.34 \pm 0.27$ & $0.34 \pm 0.30$ \\
MMS & $0.02 \pm 0.06$ & $0.40 \pm 0.32$ & $0.06 \pm 0.13$ & $0.38 \pm 0.21$ & $\mathbf{7 . 0 0} \pm \mathbf{3 . 9 4}$ & $\mathbf{4 . 0 0} \pm \mathbf{1 . 2 7} *$ & $\mathbf{1 1 . 0} \pm \mathbf{4 . 1 3} *$ & $0.86 \pm 0.52$ \\
TRI & $\mathbf{0 . 2 4} \pm \mathbf{0 . 2 0} *$ & $\mathbf{0 . 2 6} \pm \mathbf{0 . 2 7}$ & $1.00 \pm 1.22$ & $\mathbf{0 . 9 6} \pm \mathbf{0 . 5 0} *$ & $\mathbf{2 . 0 6} \pm \mathbf{1 . 3 7} *$ & $\mathbf{1 . 3 8} \pm \mathbf{1 . 5 1} *$ & $\mathbf{3 . 4 4} \pm \mathbf{1 . 8 6 *}$ & $\mathbf{4 . 8 4} \pm \mathbf{3 . 2 4} *+$ \\
\hline
\end{tabular}

NB - nuclear buds; CL - chromosomal losses; C-M - C-Metaphase; CBr - chromosomal bridge; MN - micronuclei; CB chromosomal breakages; IMut - Index of mutagenicity; IGen - Index of genotoxicity; NC - negative control (distilled water); MMS: methyl methanesulfonate; DMSO: dimethyl sulfoxide; TRI: Trifluralin. ${ }^{*} \mathrm{p}<0.05$ when compared to the negative control (Kruskal-Wallis test followed by post-hoc Tukey's test); ${ }^{+}$Other genotoxic abnormalities were found in trifluralin. 
the potential of this species to therapeutic practices, the phytochemistry evaluation of $M$. hirsuta herein presented is an essential step to develop new drugs and confirm their utility in complimentary medicine.

In fact, the raw extract and fractions obtained from leaves of $M$. hirsuta presents several secondary metabolites such as saponins, steroids, triterpenoids, phenols, tannins, anthocyanins, anthocyanidins, flavonoids (flavonols, flavanonols, and flavanones) and/or xanthones and their heterosides. These compounds have been commonly reported in other species of Bignoniaceae, confirming the key role of this family of lianas as a source of pharmaceutical bioproducts (Raju et al. 2011, Choudhury et al. 2011).

Under this perspective, several studies have demonstrated the beneficial effects of antioxidant activities of medicinal plants to control or treat diseases associated to redox stress and inflammation, such as type 2 diabetes mellitus, hypertension and degenerative pathologies (Aruoma 1998, Alves et al. 2010, Krishnaiah et al. 2011, Meena et al. 2012). Thus, the search for new species that combine antioxidant properties and reduced side effects is recommended, as evaluated for the extraction and fractions isolated from M. hirsuta.

In spite of some limitations, the method of -DPPH scavenging has been widely used in trials to assess the potential of natural products in reducing free radicals (Masoko and Eloff 2007, Shah et al. 2010). According to this strategy, products with $\mathrm{CE}_{50}$ lower at concentrations lower than $50 \mu \mathrm{g} / \mathrm{mL}$ indicate high antioxidant properties, while values ranging from $50-100 \mu \mathrm{g} / \mathrm{mL}, 100-200 \mu \mathrm{g} / \mathrm{mL}$ to above $200 \mu \mathrm{g} / \mathrm{mL}$ indicate moderate, low, and lack of antioxidant activity, respectively (Reynertson et al. 2005). Therefore, the HAF and AF are high antioxidants, as expected for polar fractions. Even though belonging to terpenes, the ursolic and oleanolic acids also presented antioxidant potential, what can be explained to their hydroxyl groups. The method based on $\mathrm{ABTS}^{\bullet+}$ radical scavenging, which has the advantage to test the activity properties of both hydrophilic and lipophilic compounds (Wojdyło et al. 2007), was also employed in the present work. Again, both extract and fractions proved to be efficient antioxidants, with the highest performance observed for HAF and AF (lower $\mathrm{CE}_{50}$ values).

Moreover, the ability of the tested compounds in reducing the peroxidation cascade of the linoleic acid was evaluated using $\beta$-carotene/linoleic acid system (Santos et al. 2015). As expected, the EAF was the most active fraction (79.4\%) since less polar fractions are usually more effective in blocking the peroxidation cascade in apolar systems (RahimiNasrabadi et al. 2013). In general, the extract and fractions of $M$. hirsuta presented distinct (but usually high) antioxidant properties according to each method. These differences are either related to the differentiated compound classes in each fraction and/or to the particularities of each essay with specific reaction mechanisms, revealing that distinct methodologies should be simultaneously employed to determine precisely the antioxidant properties of bioproducts.

Considering that all tested methods revealed antioxidant activities in the extract and fractions of $M$. hirsuta, the content of total phenols were estimated in each sample since this class of phytochemicals has been related to their antioxidant potential because of their structure and ability in chelating metals and interfering in peroxidation kinetics (Michalak 2006, Othman et al. 2007). Along with phenolic compounds, other secondary metabolites, such as steroids (Mooradian 1993), terpenes (Graßmann 2005), and saponins (Gülçin et al. 2004) also take account into the antioxidant activity of plant extracts. Indeed, the results from the present study showed no correlation $(p>0.05)$ between phenol content in $M$. hirsuta and antioxidant potential by the tested methods. Apparently, this behavior indicated that 
the diversity of chemical compounds of this plant has a synergistic antioxidant effect.

On the other hand, the clinical applicability of natural products requires a balance between their therapeutic benefits and toxic effects over normal cells. Thus, the cytotoxic potential of compounds from $M$. hirsuta against murine fibroblasts was evaluated, revealing no harmful effects of both extract and fractions in concentrations as high as $100 \mu \mathrm{g} / \mathrm{mL}$. This apparent low cytotoxicity is a promising result for further clinical studies in this species.

To refine the in vitro essays, the ability of the extract and fractions of $M$. hirsuta in protecting fibroblasts against the oxidative damages was also analyzed. Interestingly, all samples were able to prevent cell death after exposure to $\mathrm{H}_{2} \mathrm{O}_{2}$, with particular efficiency for the mixture of ursolic and oleanolic acids (UOA). This result suggests that the isolated acids of $M$. hirsuta induce an adaptive cell response, increasing their antioxidant defense mechanisms (Martin-Aragón et al. 2001). Similarly, Ovesná et al. (2006) and Tsai and Yin (2008) reported that both acids could protect cell lineages against the harmful effects of $\mathrm{H}_{2} \mathrm{O}_{2}$.

The hypoglycemiant properties of the raw extract and fractions of $M$. hirsuta was also assessed since the search for plants with antidiabetogenic potential has increased as an alternative to conventional treatment in as much as most commercial drugs have side effects (Uddin et al. 2014, Rangika et al. 2015). In addition, diabetes mellitus is one of the main issues for the high costs of public health services because of their worldwide incidence combined with high mortality and high morbidity indexes (Alarcon-Aguilar et al. 2000).

The immunosuppressive activity of the mixture of ursolic and oleanolic acids (D.M. Silva, unpublished data) place these compounds as potential candidates in treating type 2 diabetes mellitus (Sheng and Sun 2011). Moreover, both acids are able to act as antihyperlipidemic (Somova et al. 2003), hepatoprotective (Liu et al. 1995) and inhibitors of $\alpha$-amylase, an enzyme that regulates the absorption of carbohydrates in the intestine (Ali et al. 2006). Other beneficial effects against diabetes have been reported for these compounds, particularly the ursolic acid, since they increase the biosynthesis and the secretion of insulin (Castellano et al. 2013).

In this study, we confirmed for the first time the ability of compounds from $M$. hirsuta in reducing the $\alpha$-amylase activity. Since $\alpha$-amylase plays a major role in the cleavage of starch into oligosaccharides (Sales et al. 2012), amylase inhibitors have been widely used to control post-prandial hyperglycemia and obesity (Mahomoodally et al. 2012). The $\alpha$-amylase inhibition ability observed in $M$. hirsuta was related to the isolated mixture of ursolic and oleanolic acids, which presented levels of $\mathrm{IC}_{50}$ comparable to that reported in acarbose, a clinically available drug to treatment of type 2 diabetes mellitus (Ke et al. 2014).

Since the mixture of ursolic and oleanolic acids (UOA) isolated from the EAF were the most effective fraction in preventing cell death and reducing intracellular oxidation, besides presenting antioxidant properties in vitro, this fraction seems to be more suitable for clinical use. However, potential toxic, cytotoxic, genotoxic and mutagenic effects over eukaryote cells of this fraction remain unknown. Therefore, these effects were evaluated for the first time using meristem cells of $A$. cepa. Based on the tested concentrations, the UOA fraction presented no toxicity once the mean length of roots of A. cepa and had no significant effects in the mitotic index (MI) of meristem cells. A reduced value of MI would indicate cell death or interference on the kinetics of cell division, leading to developmental disorders (Rojas et al. 1993). On the other hand, increased MI suggests increased frequencies of cell division that potentially determine growth disorders, including tumors (Leme and MarinMorales 2009). Therefore, the lack of increasing or 
decreasing of MI in cells exposed to UOA fraction indicates that these compounds are not cytotoxic in vivo. Besides, the reduced and non-significant frequency of chromosomal abnormalities in meristem cells exposed to UOA fraction when compared to negative control provided additional evidence that these pentacyclic triterpenes from $M$. hirsuta have no genotoxic or mutagenic effects in the tested concentrations.

The present dataset is particularly interesting since previous studies showed a cytotoxicity of $18.62 \%$ at a concentration of $10 \mu \mathrm{g} / \mathrm{mL}$ for the total EAF from leaves of M. hirsuta (D.M. Silva, unpublished data), differing from the results obtained here for isolated mixture of acids. In fact, the phytochemistry of the EAF of $M$. hirsuta revealed that, besides these triterpenes, other metabolites are also present in this fraction (steroids, phenols, tannins, anthocyanins, anthocyanidins and flavonoids). Therefore, the cytotoxic activity previously observed in the EAF might be related to the presence or interaction of these additional constituents (Maciel et al. 2002, Shitan 2016), thus revealing the importance of bioassays and toxicity tests of isolated active compounds prior to their clinical utilization and prevention of potential side effects (Rates 2001).

In conclusion, the present results place the leaves of $M$. hirsuta as a potential source of bioproducts against oxidative and inflammatory disorders to be particularly used in traditional medicine for local communities along caatinga region. Additionally, the most effective isolated fraction, composed of a mixture of ursolic and oleanolic acids, had no cytotoxic, genotoxic or mutagenic effects in the tested systems, indicating their relative safety what remains to be further investigated under a pharmacodynamics perspective. Finally, this study also highlights the importance of conserving regional biodiversity since they might represent a rich, accessible and underestimated natural pharmacy.

\section{ACKNOWLEDGMENTS}

This work was supported by grants from Fundação de Amparo à Pesquisa do Estado da Bahia (FAPESB) (RED038/2014), Conselho Nacional de Desenvolvimento Científico e Tecnológico (CNPq) (462401/2014-6) and Coordenação de Aperfeiçoamento de Pessoal de Nível Superior (CAPES). The authors are grateful to Léia Alexandre Alves, Jorge Vitório Gomes das Neves and Tassia Liz A. dos Santos for helping in hypoglycemiant and antioxidant assays, respectively.

\section{REFERENCES}

AGRA MF, SILVA KN, BASÍLIO JLD, FRANÇA PF AND BARBOSA-FILHO JM. 2008. Survey of medicinal plants used in the region Northeast of Brazil. Braz J Pharmacogn 18: 472-508.

ALARCON-AGUILAR FJ, JIMENEZ-ESTRADA M, REYES-CHILPA R AND ROMAN-RAMOS R. 2000. Hypoglycemic effect of extracts and fractions from Psacalium decompositum in healthy and alloxan-diabetic mice. J Ethnopharmacol 72: 21-27.

ALBUQUERQUE UP, MEDEIROS PM, ALMEIDA AL, MONTEIRO JM, NETO EMFL, MELO JGM AND SANTOS JP. 2007. Medicinal plants of the caatinga (semiarid) vegetation of NE Brazil: a quantitative approach. J Ethnopharmacol 114: 325-354.

ALI H, HOUGHTON PJ AND SOUMYANATH A. 2006. Alpha-amylase inhibitory activity of some Malaysian plants used to treat diabetes; with particular reference to Phyllanthus amarus. J Ethnopharmacol 107: 449-455.

ALVES CQ, DAVID JM, DAVID JP, BAHIA MV AND AGUIAR RM. 2010. Métodos para determinação de atividade antioxidante in vitro em substratos orgânicos. Quím Nova 33: 2202-2210.

ARUOMA OI. 1998. Free radicals, oxidative trace and antioxidants in human health and diseases. Int J Biomed Sci 4: 89-96.

BERNFELD P. 1955. Amylases, $\alpha$ and $\beta$. Meth Enzymology 1: $149-158$

BRAGA FC, WAGNER H, LOMBARDI JÁ AND OLIVEIRA AB. 2000. Screening the Brazilian flora for anti-hypertensive plant species for in vitro angiotensin-I converting enzyme inhibiting activity. Phytomedicine 7 : 245-250.

BRAND-WILLIANS W, CUVELIER ME AND BERSET C. 1995. Use of free radical method to evaluate antioxidant activity. Food Sci Technol 28: 25-30. 
CAMPANA PR, BRAGA FC AND CORTES SF. 2009. Endothelium-dependent vasorelaxation in rat thoracic aorta by Mansoa hirsuta D.C. Phytomedicine 16: 456-461.

CASTELLANO JM, GUINDA A, DELGADO T, RADA M AND CAYUELA JA. 2013. Biochemical basis of the antidiabetic activity of oleanolic acid and related pentacyclic triterpenes. Diabetes 62: 1791-1799.

CHAVES SM AND REINHARD KJ. 2003. Paleopharmacology and pollen: theory, method, and application. Mem Inst Oswaldo Cruz 98: 207-211.

CHOUDHURY S, DATTA S, TALUKDAR AD AND CHOUDHURY MD. 2011. Phytochemistry of the family Bignoniaceae - a review. J Sci Technol Biol Environ Sci 7: 145-150.

DE TOLEDO CE ET AL. 2011. Antimicrobial and cytotoxic activities of medicinal plants of the Brazilian cerrado, using Brazilian cachaça as extractor liquid. J Ethnopharmacol 133: 420-425.

ELISABETSKY E AND COSTA-CAMPOS L. 1996. Medicinal plant genetic resources and international cooperation: the Brazilian perspective. J Ethnopharmacol 51: 110-120.

GRAßMANN J. 2005. Terpenoids as plant antioxidants. Vitam Horm 72: 505-535.

GUERRA MP AND NODARI RO. Biodiversidade: aspectos biológicos, geográficos, legais e éticos. 2006. In: Simões CM, Schenkel EP, Gosmann G, Mello JCP, Mentz LA and Petrovick PR (Org), Farmacognosia: da planta ao medicamento, Editora da Universidade UFRGS/ Editora da UFSC, Porto Alegre, Florianópolis, p. 13-26.

GÜLÇIN I, MSHVILDADZE V, GEPDIREMEN A AND ELIAS R. 2004. Antioxidant activity of saponins isolated from ivy: alpha-hederin, hederasaponin-C, hederacolchiside-E and hederacolchiside- F. Plant Med 70: 561-563.

HANSEN MB, NIELSEN SE AND BERG K. 1989. Reexamination and further development of a precise and rapid dye method for measuring cell growth/cell kill. J Immunol Methods 119: 203-210.

HEYWOOD V. 2011. Ethnopharmacology, food production, nutrition and biodiversity conservation: towards a sustainable future for indigenous peoples. J Ethnopharmacol 137: 1-15.

KE E, SHI JC AND MAO XM. 2014. Safety and efficacy of acarbose in the treatment of diabetes in Chinese patients. Ther Clin Risk Manag 10: 505-511.

KRISHNAIAH D, SARBATLY R AND NITHYANANDAM R. 2011. A review of the antioxidant potential of medicinal plant species. Food bioprod process 89: 217-233.

LEME DM AND MARIN-MORALES MA. 2009. Allium cepa test in environmental monitoring: A review on its application. Mutat Res 682: 71-78.

LEMOS JR AND ZAPPI DC. 2012. Distribuição geográfica mundial de plantas lenhosas da Estação Ecológica de Aiuaba, Ceará, Brasil. R Bras Bioci 10: 446-456.
LIU J, LIU Y AND KLAASSEN CD. 1995. Protective effect of oleanolic acid against chemical-induced acute necrotic liver injury in mice. Zhongguo Yao Li Xue Bao 16: 97102.

MACIEL MAM, PINTO AC AND VEIGA JR VF. 2002. Plantas medicinais: a necessidade de estudos multidisciplinares. Quím Nova 25: 429-438.

MAHOMOODALLY MF, SUBRATTY AH, GURIB-FAKIM AM, CHOUDHARY I AND KHAN NS. 2012. Traditional medicinal herbs and food plants have the potential to inhibit key carbohydrate hydrolyzing enzymes in vitro and reduce postprandial blood glucose peaks in vivo. Sci World J 2012: 1-9.

MARTIN-ARAGÓN S, HERAS B, SANCHEZ-REUS MI AND BENEDI J. 2001. Pharmacological modification of endogenous antioxidant enzymes by ursolic acid on tetrachloride-induced liver damage in rats and primary cultures of rat hepatocytes. Exp Toxicol Pathol 53: 199206.

MARTINS D, CARRION LL, RAMOS DF, SALOMÉ KS, DA SILVA PE, BARISON A AND NUNEZ CV. 2013. Triterpenes and the antimycobacterial activity of Duroia macrophylla Huber (Rubiaceae). Biomed Res Int 2013: $1-7$.

MASOKO P AND ELOFF J. 2007. Screening of twenty-four South African Combretum and six Terminalia species (Combretaceae) for antioxidant activities. Afr J Tradit Complement Altern Med 4: 231-239.

MEENA H, PANDEY KH, PANDEY P, ARYA MC AND AHMED Z. 2012. Evaluation of antioxidant activity of two important memory enhancing medicinal plants Baccopa monnieri and Centella asiatica. Indian J Pharmacol 44: 114-117.

MICHALAK A. 2006. Phenolic compounds and their antioxidant activity in plants growing under heavy metal stress. Polish J of Environ Stud 4: 523-530.

MOGHADDAM FM, FARIMANI MM, SALAHVARZI S AND AMIN G. 2007. Chemical Constituents of Dichloromethane Extract of Cultivated Satureja khuzistanica. Evid Based Alternat Med 4: 95-98.

MOORADIAN AD. 1993. Antioxidant properties of steroids. J. Steroid Biochem Mol Biol 45: 509-511.

NOGUEIRA RC, DE CERQUEIRA HF AND SOARES MB. 2010. Patenting bioactive molecules from biodiversity: the Brazilian experience. Expert Opin Ther Pat 2: 145-157.

OTHMAN A, AMIN ISMAILA A, GHANIA NA AND ADENANB I. 2007. Antioxidant capacity and phenolic content of cocoa beans. Food Chem 100: 1523-1530.

OVESNÁ Z, KOZICS K AND SLAMENOVÁ D. 2006. Protective effects of ursolic acid and oleanolic acid in leukemic cells. Mutat Res 600: 131-137.

PEREIRA JÚNIOR LR, ANDRADE AP, ARAÚJO KD, BARBOSA AS AND BARBOSA FM. 2014. Espécies 
da caatinga como alternativa para o desenvolvimento de novos fitofármacos. Floresta e Amb 21: 509-520.

RAJU S, KAVIMANI S, UMA MV AND SREERAMULU RK. 2011. Tecomastans (L.) Juss. ex Kunth (Bignoniaceae): ethnobotany, phytochemistry and pharmacology. J Pharm Biomed Sci 8: 1-5.

RAHIMI-NASRABADI M, POURMORTAZAVI SM, NAZARIAN S, AHMADI F AND BATOOLI H. 2013. Chemical composition, antioxidant, and antibacterial activities of the essential oil and methanol extracts of Eucalyptus oleosa leaves. Int J Food Prop 16: 1080-1091.

RANGIKA BS, DAYANANDA PD AND PEIRIS DC. 2015. Hypoglycemic and hypolipidemic activities of aqueous extract of flowers from Nycantus arbor-tristis L. in male mice. BMC Complement Altern Med 15: 1-9.

RATES SMK. 2001. Plants as source of drugs. Toxicon 39: 603-613.

RE R, PELLEGRINI N, PROTEGGENTE A, PANNALA A, YANG M AND RICE-EVANS C. 1999. Antioxidant activity applying an improved ABTS radical cation decolorization assay. Free Radic Biol Med Discipline 26: 1231-1237.

REYNERTSON KA, BASILE MJ AND KENNELLY EJ. 2005. Antioxidant potential of seven myrtaceous fruits. Ethnobotany Res Appl 3: 25-35.

ROCHA AD, OLIVEIRA AB, FILHO JDS, LOMBARDI JÁ AND BRAGA FC. 2004. Antifungal constituents of Clytostoma ramentaceum and Mansoa hirsuta. Phytother Res 18: 463-467.

ROJAS E, HERRERA LA, SORDO M, GONSEBATT ME, MONTERO R, RODRIGUEZ R AND OSTROSKYWEGMAN P. 1993. Mitotic index and cell proliferation kinetics for identification of antineoplastic activity. AntiCancer Drugs 4: 637-640.

RUFINO MS. Metodologia Científica: Determinação da atividade antioxidante total em frutas pela captura do radical livre DPPH. 2007. Embrapa, Comunicado Técnico 127.

SALES PM, SOUZA PM, SIMEONI LA, MAGALHÃES PO AND SILVEIRA D. 2012. $\alpha$-Amylase inhibitors: a review of raw material and isolated compounds from plant source. Eur J Pharm Sci 15: 141-183.

SANTOS MFG, MAMEDE RVS, RUFINO MSM, BRITO ES AND ALVES RE. 2015. Amazonian native palm fruits as sources of antioxidant bioactive compounds. Antioxidants 4: 591-602.

SEEBACHER W, SIMIC N, WEIS R, SAT R AND KUNERT O. 2003. Complete assignments of ${ }^{1} \mathrm{H}$ and ${ }^{13} \mathrm{C}$ NMR resonances of oleanolic acid, $18 \alpha$-oleanolicacid, ursolic acid and their 11-oxo derivatives. Magn Reson Chem 41: 636-638.

SHAH R, KATHAD H, SHETH R AND SHETH N. 2010. In vitro antioxidant activity of roots of Tephrosia purpurea Linn. Int J Pharm Sci 2: 30-33.

SHENG H AND SUN H. 2011. Synthesis, biology and clinical significance of pentacyclic triterpenes: a multi-target approach to prevention and treatment of metabolic and vascular diseases. Nat Prod Rep 28: 543-593.

SHITAN N. 2016. Secondary metabolites in plants: transport and self-tolerance mechanisms. Biosci Biotechnol Biochem 4: 1-11.

SILVA DM, SANT'ANA AEG, CASTRO MMS, QUEIROZ LP, SOARES MB AND COSTA JFO. 2015. Isolamento de triterpenos pentacíclicos: ácido ursólico e oleanólico, e fitoesteróides: estigmasterol e $\beta$-sitosterol extraídos das folhas da Mansoa hirsuta D.C. Bignoniaceae, para aplicação em formulações de suplementos, alimentos funcionais e fitoterápicos. BR. Pat 102015008180, 01 abr, 19 p.

SINGLETON VL, ORTHOFER R AND LAMUELA RM. 1992. Analysis of total phenols and other oxidation substrates and antioxidants by means of Folin-Ciocalteu reagent. Methods Enzym 299: 152-178.

SOMOVA LO, NADAR A, RAMMANAN P AND SHODE FO. 2003. Cardiovascular, antihyperlipidemic and antioxidant effects of oleanolic and ursolic acids in experimental hypertension. Phytomedicine 10: 115-121.

SOULE BP, HYODO F, MATSUMOTO K, SIMONE NL, COOK JA, KRISHNA MC AND MITCHELL JB. 2007. The Chemistry and Biology of Nitroxide Compounds. Free Radic Biol Med 42: 1632-1650.

TSAI SJ AND YIN MC. 2008. Antioxidative and antiinflammatory protection of oleanolic acid and ursolic acid in PC12 cells. J Food Sci 73: 174-178.

UDDIN N, HASAN MR, HOSSAIN MM, SARKER A, HASAN AH, ISLAM AF, CHOWDHURY MM AND RANA MS. 2014. In vitro $\alpha$-amylase inhibitory activity and in vivo hypoglycemic effect of methanol extract of Citrus macroptera Montr. fruit. Asian Pac J Trop Dis 4: 473-479.

WOJDYŁO A, OSZMIÁNSKI J AND CZEMERYS R. 2007. Antioxidant activity and phenolic compounds in 32 selected herbs. Food Chem 105: 940-949.

YARNELL E. 2000. The botanical roots of pharmaceutical discovery. J Altern Complement Med, p. 125-128.

ZOGHBI MGB, OLIVEIRA J AND GUILHON GMSP. 2009. The genus Mansoa (Bignoniaceae): a source of organosulfur compounds. Rev Bras Farmacogn 19: 795 804. 
